\title{
Genoese Traces in the Black Sea Coast of Turkey's Forts
}

\author{
Nurhilal Burak \\ Istanbul Teknik Üniversitesi, Istanbul, Turkey, nurhilalsimsek@gmail.com
}

\begin{abstract}
The Black Sea is an interior sea and located between Bulgaria, Romania, Moldova, Ukraine, Russia, Georgia and Turkey. The Black Sea flows through the Bosporus and reaches the Marmara Sea. Strong winds and stream has seen in the Black Sea in most of times in a year. Because of that natural bays were preferred while the ports and settlements were established.

Republic of Genoa has started to plan the trade routes that will be carried out on the Black Sea coast since the Treaty of Nymphaeum signed in 1261. The settlements of the Genoese colonies along the Black Sea coast were not simultaneous. From 1266 onwards, there had been a growth of about 200 years. They intervened in some of the defense structures in these ports. They have placed their own coat of arms on the walls of the defensive structures they had built or repaired. The information is obtained about the colonies in these ports from the trade records which kept by Genoese (Massaria di Caffa, Massaria di Pera), the maritime maps (portolans) produced in those centuries and the medieval historians.

The scope of this paper is to be examined that between Bulgaria and Georgia borders the Black Sea port of Turkey's remaining strongholds which Genoese used for trade. Historical documents and maps will be used as well. In the light of these methods, the ports used by the Republic of Genoa on the shores of the Black Sea, established colonies and construction activities in the thirteenth - fifteenth centuries will be examined.
\end{abstract}

Keywords: Fortress, Genoese, Black Sea, coastal fortification.

\section{Introduction}

The trade in the Black Sea coast has increased as of the second half of the thirteenth century. The reason for this acceleration is searching for a safe connection between Asia and Europe. Italian Maritime Republics have benefited from the relations with the Byzantine Empire, which was destroyed by Latin invasions and lost power. They started to establish trade colonies in these lands. These colonies were located in the trade routes associated with each other.

In the Late Middle Ages maritime republics have been established which expanding the trade network and volume by crossing long distances. These maritime republics established in Italy and played important roles in historical events and eastern trade. It is observed that the four maritime republics are prominent compared to other republics; Venice (697-1797), Genoa (10051815), Amalfi (839-1137) and Pisa (11th-1406). Other prominent republics established in Italy and engaged in maritime trade; Ragusa (13581808), Ancona (1000-1532 and Gaeta (8391140). All these maritime republics have some maritime trade routes to which they can connect with the coasts of Italy, the Adriatic Sea and the Eastern Mediterranean.

The relations of the Italian maritime republics with Byzantium have been changing in every pe- 
riod. However, it would be right to divide them into three historical sections within the framework of the treaties signed and the rights lost by these states. According to the advantages of republics in maritime trade; the first period is from 1204 (the beginning of the $4^{\text {th }}$ Crusade) -Amalfi, the second period is during the Latin occupation (1204-1261) - Venice and the third period is from 1261 to 1453 (the Ottoman conquest of Constantinople and the collapse of Byzantium) Genoa (Turan, 1990, p. 19).

\section{Genoese in the Black Sea Coasts}

The Republic of Genoa, which was established in Genoa, the capital of Liguria region in the north of Italy, declared its full independence in 1099 by leaving France sovereignty. The first trade agreement between Genoese and Byzantium was signed around 1142. The rights obtained by this treaty were similar to those of the Pisans. The most important article of the new treaty was the provision of a special place (embolum) for merchants in Constantinople to store and sell merchandise (Penna, 2012, p. 27).

During the Latin occupation in the empire of Iznik, Michael VIII Palaeologus was making plans for the conquest of Constantinople in 1259 . He wanted help from Genoese for his lack of maritime power. For this purpose, an agreement was signed between the Genoese and the Emperor on March $13^{\text {th }}, 1261$, involving mutual gains. The Treaty of Nymphaeum was signed in a district of İzmir, known as Kemalpaşa. With this treaty, the Palaeologus will re-dominate Constantinople by ending the Latin occupation and the Genoese has achieved a commercial advantage in Levante.

In this treaty, the most important article on the future trade life of the Genoese states that no nation other than Genoese and Pisa could trade in the Black Sea (Heyd, 2000, p. 482). The Venetian fortress (castrum Venetorum) in Constantinople was given to the Genoese. The number and power of the Genoese colony in the capital increased steadily. Michael VIII Palaeologus tried to keep his distance with the Genoese and give some rights to Venetians in order to distribute the balance of power in 1264 . For this reason, the Genoese was moved to the Galata (Pera) region outside the center in 1267 (Turan, 1990, p. 37).

The Genoese took control of some other important ports over time such as Edremit, Izmir, Chios, Foca, Lesbos, Enez, Imbros, Thassos, Daphnousia (Kefken), Amastris (Amasra), Sinop, Samsun, Fatsa, Trabzon, Balaklava, Caffa and Sudak (Soldaia). With the Treaty of Nymphaeum, the Genoese were given the right to allocate houses and churches in these districts, a trade center (fondaco) to maintain their own administration and to have a consul for the management of the area (Turan, 1990, p. 36; Gallotta, 1993, p. 363). Instead of controlling from the headquarter, such as Venice, the Genoese took control of the regions by assigning consuls, allowing the regions to be managed in part.

Since the earliest dates, the sea and coasts have been actively used for transportation between the coasts of the North Black Sea and the Mediterranean Sea. For this reason, there are harbor and city settlements on all sides of the Black Sea, especially on the shores with sheltered bays. Although the Black Sea is the intersection point of different civilizations, it is the contact area between east and west. For this reason, it became the center of seafarers engaged in trade. The trade routes on the Black Sea connect the Azov Sea, Western Europe, the Byzantine Empire, the Near East, Italy and the Mediterranean coast.

\subsection{Maps}

Italians have prepared maritime maps and indicated the ports where ships could anchor. From the thirteenth century onwards, these maps which prepared specially for seafarers are called portolan charts. Maps were prepared by hand drawing and handwriting. The names of the ports are red and black colored. Red-colored harbors mean more important, bigger and safer than black-colored. For this paper, original copies of Vesconte (1321), Dulcert (1339); Soler (1380), de Vallseca (1447), de Canepa (1489) and Aguiar (1492) portolan charts were used for detecting red-colored harbors.

Figure 3 shows the fortresses of the Black Sea coast and the defense structures which are redcolored in portolan charts. In addition, it shows 
where the Genoese had consuls between the thirteenth and fifteenth centuries. Some of these defense structures have been rebuilt. Some of them have been repaired, renewed or enlarged after being taken under control.

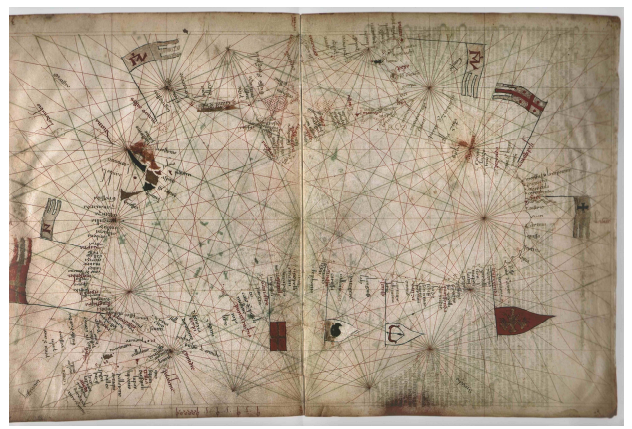

Fig. 1. Portolan Chart of Vesconte (1321).

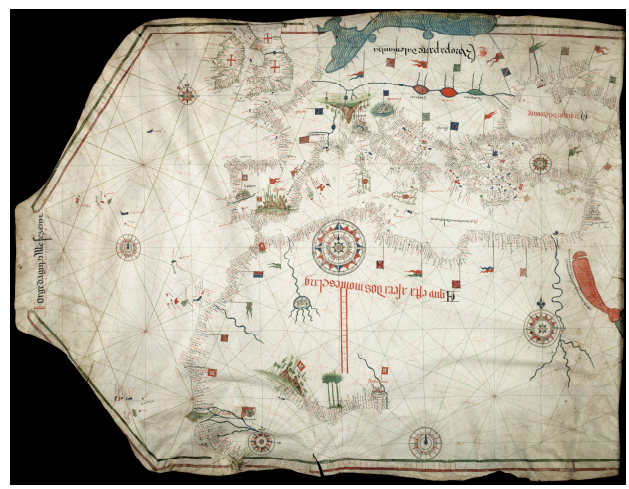

Fig. 2. Portolan Chart of Aguiar (1492).

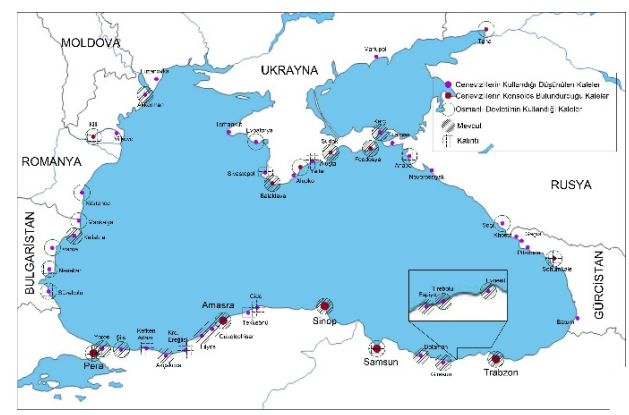

Fig. 3. Harbors in the Coast of the Black Sea.

For this figure, all ports, which are indicated with red color in portolan charts, have been identified. The fortresses where the Genoese coat of arms has been documented are marked in red. In the defense structures without Genoese coat of arms, the active and intensive construction activities of the Genoese cannot be mentioned. Massaria di Pera and Massaria di Caffa expense registries were recorded during the periods when these port cities were used by the Genoese for commercial purposes. Balard (1978) and Poplawski (2016) had interpreted partially of them.

\subsection{Genoese building activities}

The Genoese began to establish colonies on the shores of the Black Sea by the thirteenth century. It is known that some regions (colonies) use some area of (autonomous) castles or harbors for colonies. In some regions, a consul has been assigned. The consulates were responsible for the colony, trade and construction activities. In some autonomous regions where consuls are appointed, part of the fortress is arranged for the residence of the consul and other persons in charge of administration. There was also the need to build new walls against the subsequent attack threats. All these construction activities could only be possible with certain investments. The main purpose is to provide transfer by preserving the merchandise at certain points at selected intervals and by following the political processes related to the civilizations that own the land.

Genoese coats of arms are documented at Galata, Yoros, Amasra, Sinop, Samsun and Güzelhisar (Trabzon) which are located on the north coast of Turkey. The Genoese placed their own coat of arms on the upper elevations of the fortress walls they raised in the examples mentioned. Therefore, the dates of construction activities are close to certainty. The dates of the production of these plates and the dynastic family and the duty shops on the coat of arms can be almost certainly known. According to the investigations conducted on these castles, the techniques used on the walls built by the Genoese differ greatly. According to Massaria di Caffa records, Greek workers were assigned to make repairs in Feodosia, Samsun and Amasra Castle (Quirini-Poplawski, 2016, p. 131). The fact that non-Italian craftsmen and workers have been assigned to construction activities makes it impossible to search for a Genoese construction technique. 
However, when the measurements taken from the wall surfaces of the defense structures are compared, it is seen that many architectural elements are similar in Amasra and Güzelhisar Castle and the walling techniques are similar (Fig. 4). Different qualities and colors of stones were used. Dimensions of stones are min. 30 and max. $50 \mathrm{~cm}$. White colored khorasan was preferred as binder mortar. Similar size and quality of stones were preferred on the edges and the tops of the doors.

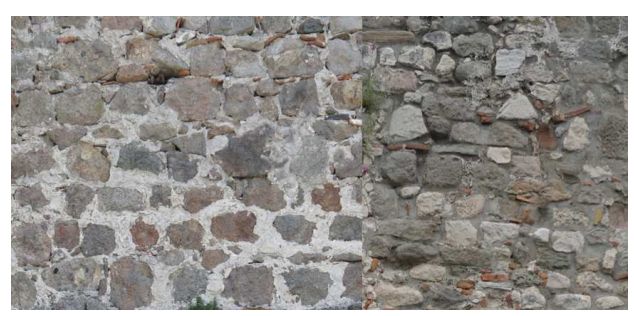

Fig. 4. Construction Techniques of Güzelhisar and Amasra Castle.

Galata Castle has not survived as a whole. At some points in the city, there are wall remains and tower structures between the new buildings. Galata Castle has been enlarged in different periods over two hundred years. Wall construction techniques in this defense structure should also be discussed in more detail in a study. The workmanship of the stones used in the walls of this rest is much more carefully shaped than the other castles mentioned. There is bicolored pattern formed by courses of three bricks and a rectangular stone arrangement in the arches. The corner stones are made up of better shaped large stones.

Today, many defense structures on the shores of the Black Sea are known as the Genoese Castle. But the difference in wall construction techniques shows that these structures are not derived from the same style and period. The main purpose of the Genoese was to defend their trade goods. Accordingly; they have strengthened the necessary defense structures at local points. Considering that craftsmen were assigned from different places for constructions, it is likely to be seen different construction techniques in the same periods.

\section{Conclusion}

Genoese is one of the largest trading nation in the past who had made the territory of Turkey. Through its fleet and maritime knowledge at sea, it has been one of the most important maritime republics throughout Byzantine and Ottoman history. They were transporting goods and slaves needed by Europe from the far east and north. It needed ports where ships could anchor in loading goods and exporting. They have made the selection of these ports very careful. They identified small regions and assigned consuls to their administration. In this way, they reached much faster solutions during periods of limited and slow interaction. Their superiority in the Black Sea lasted about two hundred years.

As it is understood from the portolan maps and written texts, autonomous areas were obtained in some ports and castles. They were able to use some regions in the thirteenth - fifteenth centuries in line with their relations with Byzantium. From the end of the Latin invasion to the conquest of Istanbul by the Ottomans, there were regions where they have dominated the land. A trade flow has also been identified between these regions. But this flow has no definite course or relationship. The main purpose was to deliver the needed materials to Europe.

A detailed study was made of the Black Sea coast in Turkey. With this study, some conclusions were reached about construction techniques. First of all, the Genoese did not carry out construction activities in every castle they used during their trade. Secondly, they produced and placed their own coats of arms on top of even the tower structures they repaired. Third, they avoided high-cost large-scale constructions. They have reached the solution with the necessary walls in line with their needs.

Lastly, they did not apply their own architectural and aesthetic flow to every building. In the region where the buildings are located, materials that are accessible were preferred. Generally, small size stones are combined with white colored khorasan mortar. In this case, the constructions are considered to be finished quickly. The better shaped large stones are observed only in some tower structures in Güzelhisar and Galata Castle. 


\section{Bibliography}

Aguiar, J. (1492). Portolan chart, The collection of Beinecke Rare Book and Manuscript Library, University of Yale, New Haven, USA, in https://en.wikipedia.org/wiki/File:Jorge_Aguiar_ 1492_MR.jpg (11 January 2018).

Balard, M. (1978). La Romanie Genoise, Atti Della Societa Ligure Di Storia Patria, Genoa.

Canepa, A. de. (1489). Portolan Chart, The collection of James Ford Bell Library, University of Minnesota, Minneapolis, in https://www.lib.umn.edu/apps/bell/map/PORTO/CAN/center.html (05 February 2018).

Dulcert, A. (1339). Portolan Chart, The collection of Bibliothèque Nationale de France, Paris, in https://en.wikipedia.org/wiki/Angelino_Dulcert (10 April 2019)

Gallotta, A. (1993). "Ceneviz", İslam Ansiklopedisi, 7, TDV, Istanbul, pp. 363-365.

Heyd, W. (1975). Yakın - Doğu Ticaret Tarihi, Karal, E.Z., trans., Türk Tarih Kurumu Yayınları, Ankara.

Penna, D. (2012). The Byzantine Imperial Acts to Venice, Pisa and Genoa, 10-12 ${ }^{\text {th }}$ Centuries, Eleven International Publishing, Den Haag.

Quirini-Poplawski, R. (2016). New Research on the Genoese Colonies - Samastri and Simisso in the First Half of the $15^{\text {th }}$ Century, Cultural Encounters in Anatolia in the Medieval Period: The Italians in Anatolia during 12-15 Centuries Symposium, 13 May 2016, Koç University \& VEKAM, Ankara.

Soler, G. (1380). Portolan Chart, The collection of Bibliothèque Nationale de France, Paris, in https://upload.wikimedia.org/wikipedia/commons/4/4f/Portolan_chart_of_Guillem_Soler_\%28c.1380\%2C_Paris \%29.jpg (08 February 2018).

Turan, Ş. (1990). Türkiye İtalya İlişkileri [Turkey and Italy Relations], Metis Yayınları, İstanbul.

Vallseca, G. (1439). Portolan Chart, Museu Maritim, Barcelona, in https://en.wikipedia.org/wiki/Gabriel_ de_Vallseca\#/media/File:Gabriel_Vallseca._Museo_Mar\%C3\%ADtimo,_Barcelona.1439.jpg $\quad(10 . \quad$ February 2018).

Vesconte, P. (1321). Portolan chart, The Bulgarian Lands in the European Cartographic Tradition, $3^{\text {rd }}-19^{\text {th }}$ c. (2008), (p. 102). Tangra Tanakra Publishing House, Ltd., Sofia, http://papacoma.narod.ru/maps/maps-images/vesconte1320-1.jpg (08 February 2018). 
